\title{
The Effect of Ownership Structure on Earnings Management Practices Toward Achieving the Real Comprehensive Income "An Applied Study on the Listed Companies in Libyan Stock Market"
}

\author{
Moutaz A. Kablan \\ Faculty of Economics - University of Benghazi \\ Financial Accounting, Benghazi, Libya \\ E-mail:moutaz.kablan@uob.edu.ly
}

Received date: 20 January 2020; Accepted date:7 May 2020; Published date: 09 June 2020

Academic Editor: Kamal Abou El Jaouad

Copyright (C) 2020. Moutaz A. Kablan. Distributed under Creative Commons Attribution 4.0

International CC-BY 4.0

\begin{abstract}
Due to the importance of presenting an integrated model to disclose the real comprehensive income, to measure the management performance fairly and to take rational decisions related to dividends away from earnings management practices, this study aimed to identify the effect of the combination of ownership structure on earnings management practices in the listed companies in the Libyan stock market, as an addition and evidence of the emerging economies like the Libyan one. The study has stated the main following hypothesis: the ownership structure has a significant effect on earnings management practices in the listed companies in the Libyan stock market. As a result, relying on a multiple regression technique, which has been used to examine the five subhypotheses of the main one, the study became able to state that the ownership structure of enormous stockholders does not have a significant effect on earnings management practices in the listed companies in the Libyan stock market, while each of the managerial ownership structure; institutional ownership structure and foreign ownership structure, has a positive significant effect on earnings management practices in the listed companies in the Libyan stock market. On the other hand, the public ownership structure has a negative significant effect on earnings management practices in the listed companies in the Libyan stock market.
\end{abstract}

Keywords: Ownership Structure- Earnings Management- Comprehensive Income

Cite this Article as: Moutaz A. Kablan (2020), " The Effect of Ownership Structure on Earnings Management Practices Toward Achieving the Real Comprehensive Income "An Applied Study on the Listed Companies in Libyan Stock Market", Journal of Accounting and Auditing: Research \& Practice, Vol. 2020 (2020), Article ID 508160, DOI: $10.5171 / 2020.508160$ 


\section{Introduction}

First and foremost, the financial statements are the most important source of information about the income, the financial position and cash flows of the firm, which are relied upon by investors, lenders, financial analysts, taxation authorities, ... etc. to take their firm-related decisions.

According to the theoretical framework of preparing and representing the financial statements by "FASB", the financial statements must declare the management evaluation fairly, to accountability about administration of the investments that given by stockholders, introductory to recontracting or decision of the board of directors (Kablan, 2019).

The costs of the agency model are a result of the separation between ownership and administration; so many problems will appear as a result of the opportunist decisions taken by the board of directors to achieve their interests against the stockholders (Hayat et al. 2018).

Nowadays, the spreading of the agency theoretical model around the world as a base to the international trade, underlying the multinational corporations, presented negative actions called earnings management. These conducts have deformed the fairness of the disclosed income per period (Bradshaw \& Sloan, 2012).

The disclosed accounting profits are the base of multi vital decisions like management re-contracting, debts agreements and dividends, so this component may be negatively influenced by a management targeted to deceive the stockholders and others through some allowed treatments relying on legitimatizing the personal estimates to achieve an untruthful income (Call, 2019).

The conceptual framework of the accounting theory had presented multifarious solutions to face this undesirable phenomenon as the disclosure of the comprehensive income, according to (SFAS, 130), restate the principles of corporate governance, reconstruction of international accounting standards and others. In this trend, Kablan (2019) added that, the recent income statement must disclose the sustainability [Corporate Social Responsibility "CSR", Corporate Environmental Responsibility "CER" and Corporate Governance] as a rational step toward calculating the real comprehensive income. So, the study has suggested a model to disclose the real comprehensive income as a fair measurement of the management performance and a trusted indicator of the rational dividends away from earnings management conducts.

According to the author of this paper's point of view, the earnings management practices will never disappear completely in spite of all the treatments which have been created. This is due to the fact that these actions are mainly behavioral, so there is a desperate need to basically change the management way of thinking.

In the same direction, Hayat et al. (2018) Stated that one of the effective ways to reduce the costs of any agency is through the managerial ownership structure, where the managers are encouraged to own the company's shares to pull together the interests of the management and the stockholders, which will be positively reflected on the firm's overall performance. Moreover, this opinion is inconsistent with the nature of the agency model, relying on the separation between the administration and the ownership. So the author proposes that for example, presenting dummy shares to the management or conditional rewards by the market price of shares for the coming period.

The ownership structure illustrates the categories of stockholders and their investments, as it is the main variable which affects the firm performance. Choi (2018) added that there are two types of firm's ownership: the concentrated 
ownership, which "indicates the limited ownership of stockholders" and the dispersed ownership, which "indicates the massive numbers of stockholders, mostly less than "5\%".

\section{Literature Review and Hypotheses Development}

There are many studies aimed to identify the nature of the relationship between ownership structure and earnings management practices. This is due to the progressive collapses and crises of the leading companies around the world within the last three decades. The literature focused on the ownership structure variable as the main control variable of agency costs (Kablan, 2019).

In the same direction, (Hassan et al. 2018; Lassoued et al. 2018; Maswadeh, 2018; Mindzak and Zeng, 2018; Osemene et al. 2018; and Tessema et al. 2018) have cared about this vital relationship.

Since accountancy is a social science with different treatments to different environments, laws, regulations and economic atmospheres, this study will be applied on the listed companies in the Libyan Stock market toward achieving the real comprehensive income untouched earnings management practices, via identifying the nature of the relationship between the ownership structure and earning conducts in the Libyan business environment.

The Libyan stock market is one of the emerging markets by World Bank "WB" identification, which has already started many economic transportation plans in parallel with the Libyan economy reforms. Moreover, Kablan (2014) added that the Libyan economy has started diverted time tables to privatize massive activities starting from the nineties of the last century, relying on the Libyan stock market.

And whereas this study aims to discover another vital variable to reduce the earnings management actions to achieve the desired real comprehensive income, it can be said that there are different results of previous studies about the nature of the relationship between the ownership structure and earnings management practices. While (Yang et al. 2008; Bao and Lewellyn, 2017; and Hassan et al. 2018) have agreed that there is a positive significant correlation between the ownership structure of enormous stockholders and earnings management, (Osemene et al. 2018 and Tessema et al. 2018) have agreed that there is a negative significant correlation between them.

In addition, (Yang et al. 2008; and Kamran and Shan, 2014) have concluded that there is a positive significant correlation between the managerial ownership and earnings management, while (Alves, 2012; and O'callaghan et al. 2018) have agreed that there is no significant relationship between them.

Also, (Lassoued et al. 2017; Hassan et al. 2018; and Lassoued et al. 2018) have presented the same results that there is a positive significant correlation between the institutional ownership and earnings management, while (Yasser et al. 2017; and San Martin, 2018) resulted that there is a negative significant correlation between them.

As for the foreign ownership structure, (Shayan-Nia et al. 2017; and Osemene et al. 2018) have agreed that there is a negative significant correlation between foreign ownership structure and earnings management. Inversely (Yasser et al. 2017) concluded that there is a positive significant correlation between foreign ownership structure and earnings management practices.

Based on all of the above, this study supports this contradiction because of the nature of accountancy as a social science, as well as the absence of the influential variable of ownership structure, as the public ownership, especially in Libya, has remained for long decades, underlying the socialist thought. So the study tries to answer the coming question: what is the nature of the relationship between the ownership structure and earnings management practices in the listed companies in the Libyan stock market

Moutaz A. Kablan, Journal of Accounting and Auditing: Research \& Practice, DOI: $10.5171 / 2020.508160$ 


toward achieving the real
comprehensive Income?

Consequently, relying on the related accounting literature, the study became able to state the main hypothesis as follows:

\section{H: The ownership structure has a significant effect on earnings management practices in the listed companies in the Libyan stock market.}

Due to the ownership structure contents of five variables, as stated earlier, the study has derived the following five subhypotheses to examine the main one:

H1: The ownership structure of enormous stockholders has a significant effect on earnings management practices in the listed companies in the Libyan stock market.

H2: $_{2}$ The managerial ownership structure has a significant effect on earnings management practices in the listed companies in the Libyan stock market.

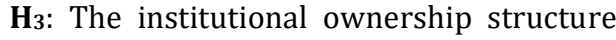
has a significant effect on earnings management practices in the listed companies in the Libyan stock market.

$\mathbf{H}_{4}$ : The foreign ownership structure has a significant effect on earnings management practices in the listed companies in the Libyan stock market.

H$_{5}$ : The public ownership structure has a significant effect on earnings management practices in the listed companies in the Libyan stock market.

\section{The Importance of the Study}

Since accountancy, as a social science, has different treatments for different economic situations, the importance of this study becomes clear in representing one of the emerging stock markets, which is the Libyan stock market, to present this unique economy toward achieving the real comprehensive income, which should fit the miscellaneous economic environments, as it has been previously said.

In addition, this study has suggested a genuine sub-variable of ownership structure, which is the public ownership structure, which represents the socialist economies around the world, like the Libyan economy.

\section{The Aim of the Study}

This study aims basically to identify the effect of the combination of ownership structure on earnings management practices in the listed companies in the Libyan stock market to present an applicable model of a desired real comprehensive income to the African and emerging economies.

\section{The methodology of the study}

At first, the methodology presents all the steps during the trail, whether theoretical or applied aspects. This section includes the following sub-contents:

\section{The method of the study}

This study is based upon the inductive approach. Having reviewed the related previous studies, this study has stated its main hypothesis and the five subhypotheses. Accordingly, the study has relied on a deductive approach by statistical analysis to examine these hypotheses to finally reach the findings and conclusion.

\section{The Applied Aspect}

This section consists of the following subsections:

\section{The population and Sample of the Study}

The population of this study consists of all the listed companies in the Libyan stock market.

As for the sample, the study has proposed a sample of ten companies which represent the indicator of the Libyan stock market, as shown in the following table (1): 
Table 1: The sample of the study

\begin{tabular}{|c|l|l|}
\hline No & \multicolumn{1}{|c|}{ The company } & \multicolumn{1}{|c|}{ The segment } \\
\hline 1 & Bank of Commerce and Development & \\
2 & Sarai Bank for commerce and Development & Banking \\
3 & BNB Paribas Group & \\
\hline 4 & Libya for Insurance & Insurance services \\
5 & United Company for Insurance & \\
6 & Sahara for Insurance & Construction \\
\hline 7 & The Libyan Company for Initialization and urban & \\
\hline 8 & Development & Industry \\
\hline 9 & The Libyan Company for Cigarettes & Investment and Financial \\
10 & The Libyan Stock Market Company & services \\
\hline
\end{tabular}

\section{The Limitations of the Study}

As an applied study, this study relies on the actual historical data for five years "20102014", to identify the effect of the combination of ownership structure on earnings management practices in the listed companies in the Libyan stock market. This era has been chosen because it has witnessed major changes in the ownership structure of many Libyan companies, like the reduction of public ownership, the entry of institutional stockholders and the entry of foreign stockholders, either institutions or human investors.

\section{The Sources of Data}

The applied aspect of the study is based on the published financial statements and periodical disclosing model of the board of directors of the ownership structure according to the disclosing regulations by the Libyan stock market authorities.

The study covers ten companies in five years, and one of these companies, "Sahara for Insurance", has a restricted data for two years "2013, 2014" only, this is because of the disciplinary sanctions that made the total of the observations of the study equal "n= 48".

All of the data of the study are available on the official website of the Libyan stock market www.lib.com.ly.

\section{The Testing of the Hypotheses}

The author has entered the data of the study by the statistical package for the social science "SPSS" to test the hypotheses of the study by a multiple regression analysis, then the author has stated the statistical models relying on the previous studies. So the statistical model to test the main hypothesis in an alternative position is as follows:

EM (it) $=B_{0}+B_{1}$ owner (it) $+B_{2}$ size (it) $+B_{3}$ prof (it) $+\sum$ (it)

\section{Knowing that}

- EM (it): Earnings management in company (i) during year $(\mathrm{t})$.

- Owner(it): ownership structure in company (i) during year $(\mathrm{t})$

- $\quad$ Size (it): size of company (i) during year $(\mathrm{t})$.

- $\quad$ Prof (it): profitability of company (i) during year $(\mathrm{t})$.

In addition, the study has stated the coming five models to test the five sub-hypotheses of the main hypothesis:

EM (it) $=B_{0}+B_{1}$ Enormous (it) $+B_{2}$ size (it) $+B_{3}$ prof (it) $+\sum$ (it) (1-1)

EM (it) $=B_{0}+B_{1}$ Managerial (it) $+B_{2}$ size (it) $+B_{3}$ prof (it) $+\sum$ (it)(1-2)

EM (it) $=B_{0}+B_{1}$ Institutional (it) $+B_{2}$ size (it) $+B_{3}$ prof (it) $+\sum$ (it)(1-3) 


\author{
EM (it) $=B_{0}+B_{1}$ Foreign (it) $+B_{2}$ size (it) \\ $+B_{3}$ prof (it) $+\sum$ (it)(1-4) \\ EM (it) $=B_{0}+B_{1}$ Public (it) $+B_{2}$ size (it) \\ $+B_{3}$ prof (it) $+\sum$ (it)(1-5)
}

\section{Knowing that:}

- Enormous (it): percentage of ownership by the biggest stockholder in company (i) during year ( $\mathrm{t}$ ).

- Managerial (it): percentage of ownership by managers in company (i) during year (t).

- Institutional (it): percentage of ownership by financial Institutions in company (i) during year $(\mathrm{t})$.

- $\quad$ Foreign (it): percentage of ownership by the foreign investors in company (i) during year $(\mathrm{t})$.

- $\quad$ Public (it): percentage of ownership by the state in company (i) during year $(\mathrm{t})$.

\section{The variables of the study and How to} measure them:

Firstly: Measuring the Dependent variable "earnings management":

This variable has been measured relying on developed optional accruals by performance, which are presented by (Kothari et al. 2005), as follows:

TAccr (it) $=\alpha_{0}+\alpha_{1}\left(1 /\right.$ Assets (it-1)) $+\alpha_{2} \Delta$ $\operatorname{Rev}(\mathrm{it})+\alpha_{3}$ PPE (it) $+\alpha_{4}$ ROA (it) $+\sum$ (it)

\section{Knowing that:}

- TAccr(it): the total of accruals, measured as [the net profit including the exceptional items of company (i) during year ( $\mathrm{t}$ )- cash flows of operational transactions of company (i) during year $(\mathrm{t})] \div$ the total of assets of previous year $(\mathrm{t}-1)$

- Asset(it-1): the total of assets at the end of previous year ( $\mathrm{t}-1)$

- $\Delta$ Rev (it): [the annual change in revenues of company (i) during year $(\mathrm{t})] \div$ the total of assets of previous year $(\mathrm{t}-1)$

- PPE (it): [tangible fixed assets for company (i) at the end of year $(\mathrm{t})] \div$ the total of assets of previous year ( $\mathrm{t}$ 1).

- ROA: return of assets of company (i) during year $(\mathrm{t})$.

- $\alpha 1, \quad \alpha 2, \quad \alpha 3, \quad \alpha 4$ : the model's parameters.

Secondly: Measuring the independent variable "ownership structure":

The study has collected the pattern of ownership of the sample by disclosing the companies about their ownership structures according to the obligatory supplementary disclosure, by the supervised board of the Libyan stock market during (2010- 2014).

This independent variable has been derived to five sub-independent variables, as stated earlier, which the study will measure consistently in accordance with (Osemene et al. 2018; o'callaghan et al. 2018; marting Regna, 2018; and Tessema et al. 2018) as follows :

- The ownership structure of enormous stockholders: has been measured by the percentage of the ownership of the biggest stockholder.

- The managerial ownership structure: has been measured by the percentage of the ownership of the supreme administration.

- The institutional ownership structure: has been measured by the percentage of the ownership of these institutions (banks, insurance companies... etc.) of the total stocks.

- The foreign ownership structure: has been measured by the percentage of the ownership of foreign investors.

- The public ownership structure: has been measured by the percentage of ownership of public firms of the total stocks.

Thirdly: Measuring the controller variables:

These variables have been measured relying on the studies of (O'callaghan et al. 2018; Osemene et al. 2018; San Martin Reyna, 2018; and Tessema et al. 2018) as follows : 
1- Size of the company: has been measured by the natural logarithm of the total assets.

2- Profitability of the company: has been measured by [net profit without interests and taxes] $\div$ [total of assets]

= Return of Assets "ROA".

\section{The Results of the Applied study}

The author has tested the five subhypotheses which were formulated in the statistical models by " $\alpha=0.05 "$.
The study has used "KolmogorovSimonov" to identify whether the data are normally distributed or not.

- The Results of the "KolmogorovSimonov" test:

According to table (2), the results of the test illustrate that the data are normally distributed "parametric", due to the Asymp. Sig "p-values" of all the variables are greater than " $\alpha=$ $0.05 "$.

Table 2: Kolmogorov- Simonov test

\begin{tabular}{|l|c|c|}
\hline \multirow{2}{*}{\multicolumn{1}{|c|}{ Variables }} & \multicolumn{2}{|c|}{ One sample Kolmogorov- Simonov } \\
\cline { 2 - 3 } & Kolmogorov-z & Asymp. Sig \\
\hline Earning management "EM" & 1.469 & 0.213 \\
Enormous stockholders & 0.987 & 0.269 \\
Managerial ownership & 0.913 & 0.946 \\
Institutional ownership & 0.861 & 0.583 \\
Foreign ownership & 1.135 & 0.261 \\
Public ownership & 0.569 & 0.371 \\
Size & 0.869 & 0.415 \\
Profitability & 0.391 & 0.791 \\
\hline
\end{tabular}

- The Descriptive Analysis:

Table (3) shows the means, standard deviations, and Highest and lowest values of all the study's variables.

Table 3: The Descriptive Analysis

\begin{tabular}{|l|c|c|c|c|c|}
\hline \multicolumn{1}{|c|}{ Variables } & $\mathrm{N}$ & Mean & $\begin{array}{c}\text { Std } \\
\text { deviation }\end{array}$ & Min & Max \\
\hline Earnings management "EM" & 48 & 6.516 & 0.518 & 1.392 & 15.817 \\
Enormous stockholders & 48 & 16.781 & 3.591 & 10.891 & 20.816 \\
Managerial ownership & 48 & 17.215 & 2.593 & 16.917 & 20.998 \\
Institutional ownership & 48 & 3.19 & 0.981 & 0.00 & 17.913 \\
Foreign ownership & 48 & 5.172 & 2.831 & 0.00 & 20.983 \\
Public ownership & 48 & 9.263 & 3.461 & 5.681 & 19.815 \\
Size & 48 & 6.531 & 0.824 & 2.891 & 10.851 \\
Profitability & 48 & 2.671 & 0.254 & 0.00 & 6.523 \\
\hline
\end{tabular}

\section{- The Results of Testing The first sub- Hypothesis:}

$\mathrm{H}_{1}$ : The ownership structure of enormous stockholders has a significant effect on earnings management practices in the listed companies in the Libyan stock market. 
Table 4: The Results of Testing the first Sub-Hypothesis

\begin{tabular}{|c|c|c|c|c|}
\hline$\beta$ & t-value & Sig. & Adjusted $\mathrm{R}^{2}$ \\
\hline 0.011 & 0.028 & 0.510 & $\% 29.5$ & (1-1) \\
\hline \multicolumn{2}{|c|}{$\mathrm{EM}(\mathrm{it})=\mathrm{B}_{0}+\mathrm{B}_{1}$ Enormous(it) $+\mathrm{B}_{2}$ Size(it) $+\mathrm{B}_{3}$ Prof(it) $+\sum(\mathrm{it})$} \\
\hline
\end{tabular}

$N=48, \alpha=0.05$

According to the statistical analysis of model (1-1), the study has concluded that there is no significant correlation relationship between the ownership structure of enormous stockholders and earnings management practices.

Calculated as $(\mathrm{p}$-value $=0.510)>(\alpha=0.05)$, this sub-independent variable doesn't affect the dependent variable "earnings management practices".
Consequently, the study rejected this subhypothesis $\left(\mathrm{H}_{1}\right)$.

\section{- The Results of Testing The second sub-Hypothesis:}

$\mathrm{H}_{2}$ : The managerial ownership structure has a significant effect on earnings management practices in the listed companies in the Libyan stock market.

Table 5: The Results of Testing the second Sub-Hypothesis

\begin{tabular}{|c|c|c|c|}
\hline$\beta$ & $\mathrm{t}$-value & Sig. & Adjusted $\mathrm{R}^{2}$ \\
\hline 0.997 & 6.46 & 0.000 & $\% 92.5$ \\
\hline \multicolumn{2}{|r|}{$\mathrm{EM}(\mathrm{it})=\mathrm{B}_{0}+\mathrm{B}_{1}$ Managerial(it) $+\mathrm{B}_{2}$ Size(it) $+\mathrm{B}_{3}$ Prof(it) $+\sum(\mathrm{it})$} \\
\hline
\end{tabular}

$N=48, \alpha=0.05$

According to the statistical analysis of model (1-2), the study has concluded that (adjusted $\mathrm{R}^{2}=0.925$ ). This means that $\% 92.5$ of the changes happening in earnings management practices can be explained by the managerial ownership structure.

In addition, the results of the statistical analysis confirm the significance of this effect, where it calculated ( $p$-value $=0.000$ ) $<(\alpha=0.05)$, so this sub-independent variable significantly affects the dependent variable "earnings management practices". So, to test this model, the study has used the " $\mathrm{t}$ " test, then the factor $=0.997$ and $\mathrm{t}$ value $=6.46$.
This means that the managerial ownership structure has a positive significant effect on earnings management practices.

Based on all of above, the study accepted this sub-hypothesis.

\section{- The Results of Testing the Third Sub-Hypothesis:}

$\mathrm{H}_{3}$ : The Institutional ownership structure has a significant effect on earnings management practices in the listed companies in the Libyan stock market.

Table 6: The Results of Testing the Third Sub-Hypothesis

\begin{tabular}{|c|c|c|c|}
\hline$\beta$ & t-value & Sig. & Adjusted $\mathrm{R}^{2}$ \\
\hline 0.68 & 1.43 & 0.000 & $\% 64$ \\
\hline \multicolumn{3}{|c|}{$\mathrm{EM}(\mathrm{it})=\mathrm{B}_{0}+\mathrm{B}_{1}$ Institutional(it) $+\mathrm{B}_{2}$ Size(it) $+\mathrm{B}_{3}$ Prof(it) $+\sum(\mathrm{it})$} \\
\hline
\end{tabular}

$N=48, \alpha=0.05$ 
According to the statistical analysis of model (1-3), the study has concluded that (adjusted $\mathrm{R}^{2}=0.640$ ). This means that $\% 64$ of the changes happening in earnings management practices can be explained by the institutional ownership structure.

In addition, the results of the statistical analysis confirm the significance of this effect, where it calculated ( $\mathrm{p}$-value $=0.000)$ $<(\alpha=0.05)$, so this sub-independent variable significantly affects the dependent variable "earnings management practices". So, to test this model, the study has used the " $t$ " test, then the factor $=0.68$ and $t$ value $=1.43$.
This means that the institutional ownership structure has a positive significant effect on earnings management practices.

Based on all of above, the study accepted this sub-hypothesis.

\section{- The Results of Testing the Fourth Sub-Hypothesis:}

$\mathrm{H}_{4}$ : The Foreign ownership structure has a significant effect on earnings management practices in the listed companies in the Libyan market.

Table 7: The Results of Testing the Fourth Sub-Hypothesis:

\begin{tabular}{|c|c|c|c|}
\hline$\beta$ & t-value & Sig. & Adjusted $\mathrm{R}^{2}$ \\
\hline 0.91 & 3.85 & 0.000 & $\% 88.20$ \\
\hline \multicolumn{3}{|c|}{ EM(it)= $\mathrm{B}_{0}+\mathrm{B}_{1}$ Foreign(it) $+\mathrm{B}_{2}$ Size(it) $+\mathrm{B}_{3}$ Prof(it) $+\sum$ (it) } \\
\hline
\end{tabular}

$N=48, \alpha=0.05$

According to the statistical analysis of model (1-4), the study has concluded that (adjusted $\mathrm{R}^{2}=0.882$ ). This means that $\% 88.2$ of the changes happening in earnings management practices can be explained by the foreign ownership structure.

In addition, the results of the statistical analysis confirm the significance of this effect, where it calculated ( $\mathrm{p}$-value $=0.000$ ) $<(\alpha=0.05)$, so this sub-independent variable significantly affects the dependent variable "earnings management practices". So, to test this model, the study has used the " $t$ " test, then the factor $=0.91$ and $t$ value= 3.85 .
This means that the foreign ownership structure has a positive significant effect on earnings management practices.

Based on all of above, the study accepted this sub-hypothesis, where there is a positive significant correlation between the foreign ownership structure and earnings management practices.

\section{- The Results of Testing the Fifth Sub-Hypothesis:}

H5: The public ownership structure has a significant effect on the earnings management practices in the listed companies in the Libyan stock market.

Table 8: The Results of Testing the Fifth Sub-Hypothesis:

\begin{tabular}{|c|c|c|c|c|}
\hline$\beta$ & t-value & Sig. & Adjusted $\mathrm{R}^{2}$ & \multirow{3}{*}{$(1-5)$} \\
\hline $0.72-$ & $1.75-$ & 0.000 & $\% 64.5$ & \\
\hline \multicolumn{4}{|c|}{$\mathrm{EM}(\mathrm{it})=\mathrm{B}_{0}+\mathrm{B}_{1}$ public(it)+ $\mathrm{B}_{2} \operatorname{Size}(\mathrm{it})+\mathrm{B}_{3} \operatorname{Prof}(\mathrm{it})+\sum(\mathrm{it})$} & \\
\hline
\end{tabular}

$N=48, \alpha=0.05$

According to the statistical analysis of model (1-5), the study has concluded that (adjusted $\mathrm{R}^{2}=0.645$ ). This means that $\% 64.5$ of the changes happening in earnings management practices can be explained by the public ownership structure.

In addition, the results of the statistical analysis confirm the significance of this effect, where it calculated ( $p$-value $=0.000$ ) 
$<(\alpha=0.05)$, so this sub-independent variable significantly affects the dependent variable "earnings management practices". So, to test this model, the study has used the " $t$ " test, then the factor $=1.75-$.

This means that the public ownership structure has a negative significant effect on earnings management practices.

Based on all of above, the study accepted this sub-hypothesis, where there is a negative significant correlation between the public ownership structure and earnings management practices.

\section{The summarized Results}

It is possible to summarize the applied results as follows:

- The ownership structure of enormous stockholders does not have a significant effect on earnings management practices in the listed companies in the Libyan stock market.

- The management ownership structure has a positive significant effect on earnings management practice in the listed companies in the Libyan stock market.

- The institutional ownership structure has a positive significant effect on earnings management practices in the listed companies in the Libyan stock market.

- The foreign ownership structure has a positive significant effect on earnings management practices in the listed companies in the Libyan stock market.

- The public ownership structure has a negative significant effect on earnings management practices in the listed companies in the Libyan market.

\section{Conclusion}

The study aimed to identify the effect of the combination of ownership structure on earnings management practices in the listed companies in the Libyan stock market to achieve the real comprehensive income.

The importance of the study stems from the nature of accountancy as a social science, where the Libyan business atmosphere is different from others. This is basically due to the nature of the Libyan economy. Also, the identification of the nature of the relationship between the ownership structure and earnings management practices in the Libyan companies will represent a vital contribution to achieve the desired real comprehensive income in line with the variation of all economies around the world.

In conclusion, the study reached that the ownership structure of enormous stockholders does not have a significant effect on earnings management practices in the listed companies in the Libyan stock market, while each of the managerial ownership structure; institutional ownership structure and foreign ownership structure, has a positive significant effect on earnings management practices in the listed companies in the Libyan stock market.

On the other hand, the public ownership structure has a negative significant effect on earnings management practices in the listed companies in the Libyan stock market.

\section{References}

1) Alves, S M. (2012), Ownership Structure and Earnings Management Evidence from Portugal, Australasian Accounting: Business and Finance Journal, 6(2), 57-74.

2) Bao, SRand Lewellyn, K. (2017), Ownership Structure and Earnings Management in Emerging Markets: An Institutionalized Agency Perspective, International Business Review, 26(5), 828-838.

3) Bradshaw, MTand Sloan, R. (2012), GAAP Versus the Street: An Empirical Assessment of Two Alternative Definition of Earnings, Journal of Accounting Research, 40 (1), 1 - 20.

4) Call, J E. (2019), A Challenge to Business Leaders to End Earnings Management, Journal of Accounting and Finance, 19(4), 55-76. 
5) Hassan, YA., Muhtaseb, H.and Hijazi, R. (2018), Influence of Board and Ownership Structure on Earnings Management: Evidence from Palestine, $8^{\text {th }}$ Annual International Conference on Accounting and Finance - AF 2018, 129 - 137 .

6) Hayat, MU., Yan, Y., Man, W.and Jebran, K. (2018) Impact of Managerial and Institutional Ownership on Capital Structure: A Comparison Between China and USA, European Journal of Business and Management, 10 (24), 69-80.

7) Kablan, M A. (2014), Measuring the Effect of the Financial Reports on the Efficiency of the Libyan Securities and Exchange Market Underlying the Privatization Policy: An Empirical Study, Ph. D Dissertation, Ain Shams University.

8) Kablan, M A. (2019), A Suggested Model to Disclosing About the Real Comprehensive Income as a Fair Measure for the Management Performance and Trusty Indicator for Mature Dividends: A Theoretical Study, Journal of Research and EconomicStudies, 3 (2), 171-205.

9) Kamran, KA.,and Shah, A. (2014), The Impact of Corporate Governance and Ownership Structure on Earnings Management Practices: Evidence from Listed Companies in Pakistan, The Lahore Journal of Economics, 19 (2), 27-70.

10) Kothari, SP.,Leone, A. and Wesley, C. (2005), Performance Matched Discretionary Accrual Measures, Journal of Accounting and Economics, 39 (1), 163-197.

11) Lassoued, NA.,Attia, M.and Sassi, H. (2018), Earnings Management in Islamic and Conventional Banks: Does Ownership Structure Matter? Evidence from the MENA Region, Journal of
International Accounting, Auditing and Taxation, 30 (1), 85-105.

12) Lassoued, NA., Banerjee, A.and Sassi, H. (2017), Earnings Management and Ownership Structure in Emerging Market: Evidence from Banking Industry, Managerial Finance, 22 (1), 205-227.

13) Maswadeh, SA. (2108), The Effect of the Ownership Structure on Earnings Management Practices, Investment Management and Financial Innovations, 15 (4), 48-60.

14) Mindzak, JAand Zeng, T. (2018), The Impact of Pyramid Ownership on Earnings Management, Asia Review of Accounting, 26 (2), 208-224.

15) O'Callagh, S., Ashton, J.and Hodgkinson, L. (2018), Earnings Management and Managerial Ownership in Private Firms, Journal of Applied Accounting Research, 19 (4), 648-668.

16) Osemene, O., Adeyele,J.and Adinnu, P. (2018), The Impact of the Ownership Structure and Board Characteristics on Nigeria's Listed Deposit Money Banks, Ekonomski Horizonti, 20 (3), 215227.

17) San Martin Reyna, J M. (2018), The Effect of Ownership Composition on Earnings Management: Evidence for the Mexican Stock Exchange, Journal of Economics, Finance and Administrative Science, 23 (46), 289305.

18) Tessema, AB., Kim, M.and Dandu, J. (2018), The Impact of Ownership Structure on Earnings Quality: The Case of South Korea, International Journal of Disclosure and Governance, Vol 15 (3), 129-141.

19) Yang, C.,Lai, H., Leing, T.and Tan, B. (2008), Managerial Ownership and Earnings Management, Journal of Financial Reporting and Accounting, 6 (1), pp 35-53.

20) Yasser, Q., Mamun, A.and Hook, M. (2017), The Impact of Ownership Structure on Financial Reporting Quality in the East,International Journal of Organizational Analysis, 25 (2), 178-197. 